\title{
THE OXYGEN COST OF BREATHING IN TETRAPLEGIC PATIENTS
}

\author{
By J. R. Silver, M.B., B.S., M.R.C.P.Ed. \\ National Spinal Injuries Centre, Stoke Mandeville Hospital, Aylesbury, England
}

\section{INTRODUCTION}

THERE is a high initial mortality from ventilatory failure among patients who have sustained an injury to their cervical cords. Tribe (1963) found that the cause of death in eight out of eleven such patients was bronchopneumonia or pulmonary embolism. The pathological changes in the lungs may be due to the paralysis of the respiratory muscles, in particular the diaphragm, intercostal and abdominal muscles, combined with the profound loss of vasomotor control and the enforced recumbency accompanying such a high cord injury.

The paralysis of the abdominal muscles makes it impossible to clear secretions from the back of the throat since coughing is weak, and the paralysis of the abdominal and intercostal muscles leads to a reduced ventilatory excursion of the chest so that certain pulmonary segments are not adequately ventilated and are more liable to collapse and infection. The enforced recumbency makes these patients more liable to aspiration and hypostatic pneumonia, and to deep vein thrombosis in the lower limbs. These lethal complications raise many problems in the early treatment of these patients, such as the indications and timing of tracheotomy combined with the use of assisted ventilation, the correct use of suction apparatus and physiotherapy to remove secretions, and furthermore the value of oxygen, prophylactic antibiotic and anticoagulant therapy.

In order to put therapy on a rational basis it is desirable to gain as much knowledge as possible about the mechanics of breathing in tetraplegic patients. Studies of pulmonary function in such patients have been carried out by Gilliatt, Guttmann and Whitteridge (1947), Cameron, Scott, Jousse and Botterell (1955), Talbot, Rocco and Conroy (1957), Wingo (1957), Hemingway, Bors and Hobby (1958) and Grossiord, Jaeger-Denavit and Anamaria Miranda (1963). These have been concerned with measurements of the lung volumes and their modification by change of posture, analysis of blood and alveolar gas samples and electromyographic investigations of the role of the shoulder girdle muscles in respiration. However, there have been no studies of the oxygen cost of breathing in these patients.

Cournand and Richards (1954), McKerrow and Otis (1956) and Campbell, Westlake and Cherniak (1957) have described methods of measuring the oxygen consumption of the respiratory muscles in man in health and disease. They have shown that in normal subjects this is insignificant (fig. I) but in patients with cardiopulmonary disorders it may rise to disproportionately high levels and thus contribute to the patients' disability.

It seemed, therefore, worthwhile to study the oxygen cost of breathing in patients with injuries to their cervical cords who had a complete paralysis of their intercostal and abdominal muscles.

\section{CLINICAL MATERIAL}

Eleven tetraplegic patients with completely paralysed intercostal and abdominal muscles were studied. The age of these patients ranged from I 8 to 45 years; there 
DISTRIBUTION OF OXYGEN CONSUMPTION IN A NORMAL SUBJECT AT REST UNDER USUAL INDOOR CONDITIONS

Weight $70 \mathrm{~kg}$. Surface area $1 \cdot 7 / \mathrm{m}^{2}$

\begin{tabular}{|l|c|c|}
\hline \multicolumn{1}{|c|}{ Circulation } & $\begin{array}{c}\mathrm{O}_{2} \text { uptake } \\
(\mathrm{ml} / \mathrm{min})\end{array}$ & $\%$ of total \\
\hline Splanchnic & 58 & 25 \\
\hline Renal & 16 & 7 \\
\hline Cerebral & 46 & 20 \\
\hline Coronary & 27 & 11 \\
\hline Skeletal muscle & 70 & 30 \\
\hline Skin & 5 & 2 \\
\hline Other organs & 12 & 5 \\
\hline \multicolumn{1}{|c|}{ Total } & 234 & - \\
\hline $\begin{array}{l}\text { RESPIRAIORY } \\
\text { MUSCLES }\end{array}$ & $1 \mathrm{ml}$ & \\
\hline
\end{tabular}

FIG. I

Oxygen consumption of the different tissues of the body modified from O. L. Wade and J. M. Bishop (I962) 'Cardiac Output and Regional Blood Flow', Blackwell, p. 93. The oxygen consumption of the respiratory muscles is insignificant compared with that of the rest of the body. (Cournand and Richards, 1954.)

were nine men and two women. They were all paralysed as a result of injuries to their spinal cords following fracture or fracture dislocations of the cervical vertebral column between 3 months and $4 \frac{1}{2}$ years previously. All had complete physiological interruptions of their cords between the 5 th and 8th cervical segments. Only one patient had a little sensory sparing to $\mathrm{T}_{3}$ segment. They were mobile in wheelchairs carrying out a normal programme of physiotherapy and occupational therapy at the Spinal Centre. They were fit adults with no history of respiratory disease prior to their injury. Seven of the patients had urinary infections; four of them were severe with frequent outbursts of sweating.

Further clinical details are given in Table I.

\section{METHODS}

Two main techniques have been used previously to measure the oxygen cost of breathing. That originally described by Liljestrand (I9I8) and followed by Cournand and Richards (1954), McKerrow and Otis (1956) and Davidson and Cayler (1963) requires the accurate analysis of samples of expired air at different levels of ventilation. The other technique devised by Campbell, Westlake and Cherniak (1957) which was used in the present study, does not require such analysis but estimates the oxygen uptake by recording the disappearance of oxygen from a closed-circuit spirometer. It is a relatively simple technique and does not require 
TABLE I

The clinical details of I I tetraplegic patients.

\begin{tabular}{|c|c|c|c|c|}
\hline Name & Age & Sex & $\begin{array}{c}\text { Complete } \\
\text { Transverse Spinal Cord Syndrome }\end{array}$ & $\begin{array}{l}\text { Time Since } \\
\text { Injury }\end{array}$ \\
\hline R. M. & 23 & Male & Below $\mathrm{C}_{5}$ due to frac. disloc. $\mathrm{C}_{5} / 6$ & I year \\
\hline D. P. & 26 & Male & Below $\mathrm{C}_{5}$ due to frac. disloc. $\mathrm{C}_{4}$ & 3 months \\
\hline F. J. H. & 24 & Male & Below $\mathrm{C}_{5}$ due to frac. disloc. $\mathrm{C}_{4} / 5$ & $4 \frac{1}{2}$ years \\
\hline R. B. H. & $2 I$ & Male & Below $\mathrm{C}_{5}$ due to frac. disloc. $\mathrm{C}_{5} / 6$ & I year \\
\hline E. H. H. & 45 & Male & Below C6 due to fracture $\mathrm{C}_{5}$ & Io months \\
\hline J. F. H. & 32 & Male & Below C6 due to fracture C5 \& 6 & $3 \frac{1}{2}$ years \\
\hline D. T. & $2 \mathrm{I}$ & Female & Below C6 due to frac. disloc. $\mathrm{C}_{5} \& 7$ & 5 months \\
\hline F. H. & 22 & Male & Below $C_{7}$ due to frac. $C_{5} \& 6$ & I5 months \\
\hline P. A. W. & 20 & Female & Below $\mathrm{C}_{7}$ due to frac. disloc. $\mathrm{C}_{5} \& 6$ & $\begin{array}{l}3 \text { years } \\
8 \text { months }\end{array}$ \\
\hline M. O. & I8 & Male & Belo & 5 months \\
\hline J. F. HG. & 22 & Male & Below $\mathrm{T}_{3}$ due to $\mathrm{fr}$ & 8 months \\
\hline
\end{tabular}

expensive equipment; it permits the oxygen uptake and ventilation to be measured with great accuracy. The principle of the method is that the oxygen consumption of a subject is determined at rest and then at various levels of ventilation. Any increase in the oxygen consumption above basic levels can be attributed to the increased uptake of the respiratory muscles and the heart at the higher levels of ventilation.

Oxygen consumption was measured by recording the disappearance of oxygen from a closed-circuit spirometer incorporating a carbon dioxide absorber. The spirometer employed was a six litre water-filled Palmer lung-volume type with a motor blower to reduce resistance. The oxygen consumption and ventilation were determined from the spirometer tracing and corrected to standard temperature and pressure (S.T.P.) and body temperature and pressure saturated (B.T.P.S.) respectively. Ventilation was measured at rest and increased by interposing varying amounts of dead space between the mouth of the subject and the spirometer circuit. The dead space consisted of varying lengths of thick-walled rubber tubing of $2 \frac{1}{2} \mathrm{~cm}$. internal diameter. The vital capacity was measured on the same spirometer and corrected to B.T.P.S.

\section{PROCEDURE}

The subjects were studied on two or three successive days. They were given nothing to eat from midnight and taken in their beds to the laboratory the following morning. They were connected to the apparatus, and two or three resting readings were taken for periods of seven to ro minutes. Then various lengths of rubber tubing were interposed between the subject and the spirometer to increase the ventilation and a further series of readings were taken. The subject was allowed to rest for five minutes between each run and to breathe through the tubing for periods varying from three to five minutes, to accustom him to the different sensation 
produced by breathing through the rubber tubing. (Figure 2 shows patient R.M. during a recording.)

A series of seven to fourteen readings were taken on each day, the final reading always being a repeat oxygen consumption to ensure that there had been no change in the patient's resting metabolic state during the procedure. The whole series would take between two to three hours per session.

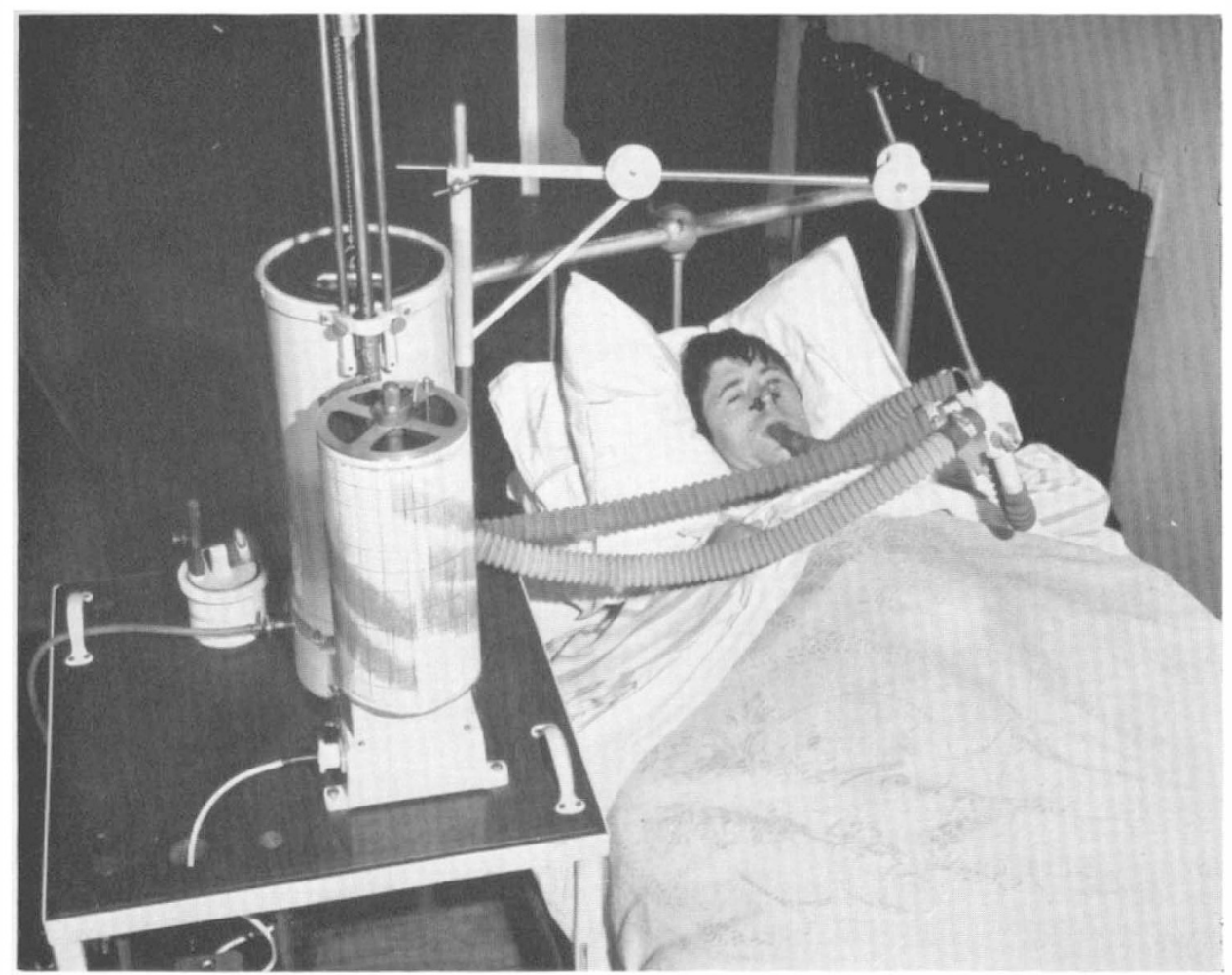

FIG. 2

Patient R. M. connected to the spirometer with some thick-walled rubber tubing interposed between his mouth and the spirometer circuit. The tracing on the drum records the ventilation and the oxygen consumption.

The first day's determinations were used to accustom the subject to the apparatus and the different sensation produced by breathing through the rubber tubing. These readings were discarded as they were too irregular and uneven to obtain satisfactory tracings to measure the oxygen consumption.

\section{RESULTS}

A series of tracings were obtained for each patient at different levels of ventilation. Figure 3 shows a representative example. The ventilation was measured directly from the tracing and corrected to B.T.P.S. The oxygen consumption in millilitres per minute was derived from the slopes of the tracings and corrected to 


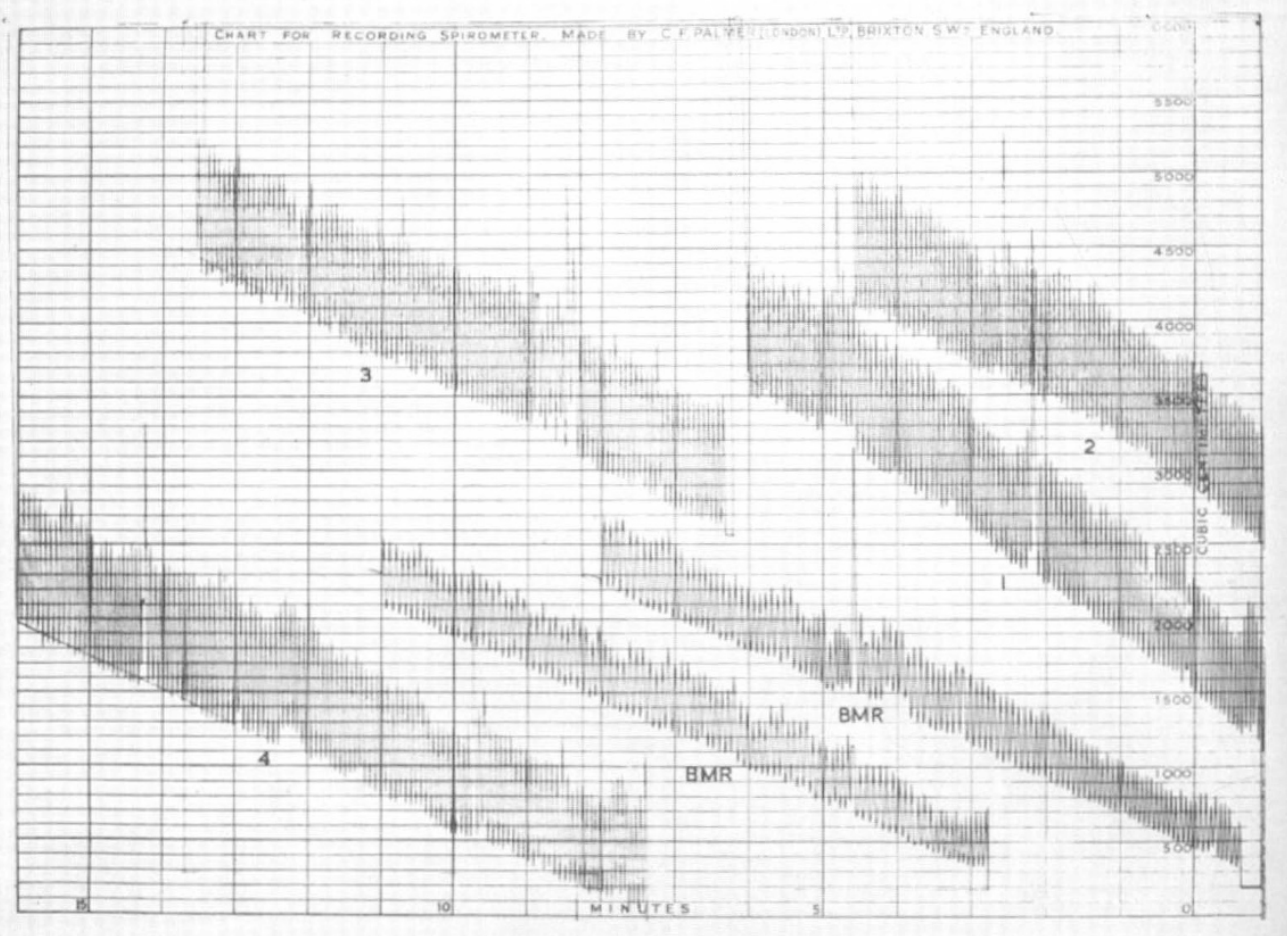

FIG. 3

A series of readings obtained from case R. M. The horizontal divisions represent minutes and the vertical divisions millilitres of oxygen. The tracings are those of ventilation, the upwards deflection being the inspiratory phase, downwards expiratory. The ventilation per minute can be obtained directly, and the oxygen consumption is obtained from the slope of the tracing, the readings being corrected to B.T.P.S. and S.T.P. respectively.

S.T.P. It was thus possible to derive the oxygen consumption of the whole body for any given level of ventilation. All the determinations carried out over a series of days were recorded. Graphs were constructed of the total oxygen consumption plotted against ventilation. Figures 4,5 and 6 show three examples. As shown in the graphs the oxygen consumption in ml. per minute is plotted vertically and the ventilation in litres per minute horizontally. There was close agreement in all three cases in the level of resting ventilation, which was a little in excess of 5 litres per minute compared with a normal subject's 6 litres per minute as described by Comroe et al. (1962). The maximum level achieved was more variable. In the figures shown it was 25 litres (in D.P.) but two other patients (M.O. and E.H.H., see Table II) achieved levels of over 29 litres. No patient could sustain higher levels of ventilation as they all complained of weakness, exhaustion and headaches at this point.

The oxygen consumption at rest was also variable. In two of the subjects shown in Figures 5 and 6 (F.J.H. and D.P.) it was $200 \mathrm{ml}$. and in one (in Figure 4, J.F.H.) it was $140 \mathrm{ml}$. 


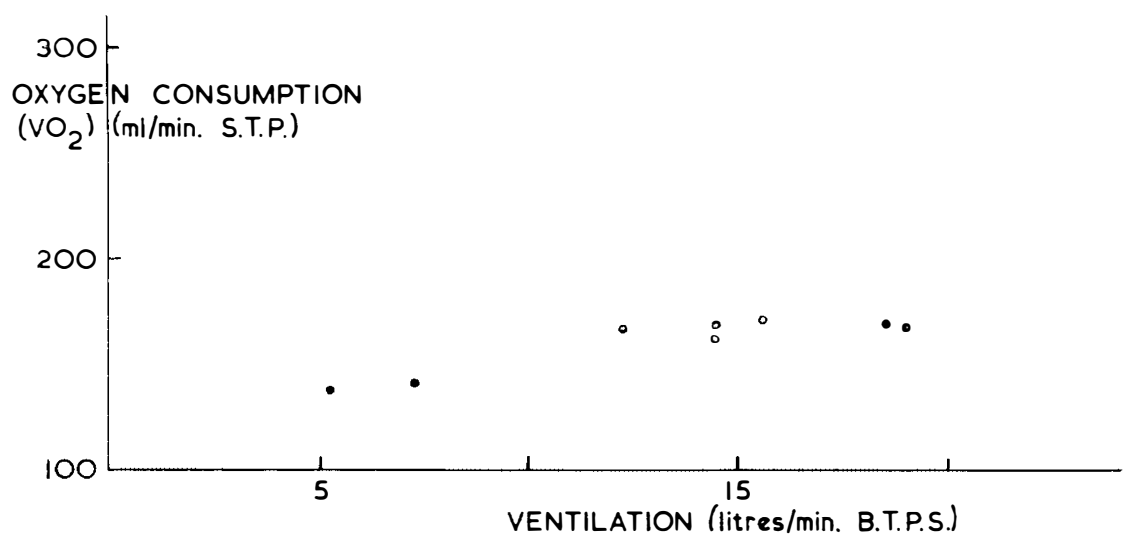

FIG. 4

C6 lesion J.F.H. Age 32 Injury 29.3.59

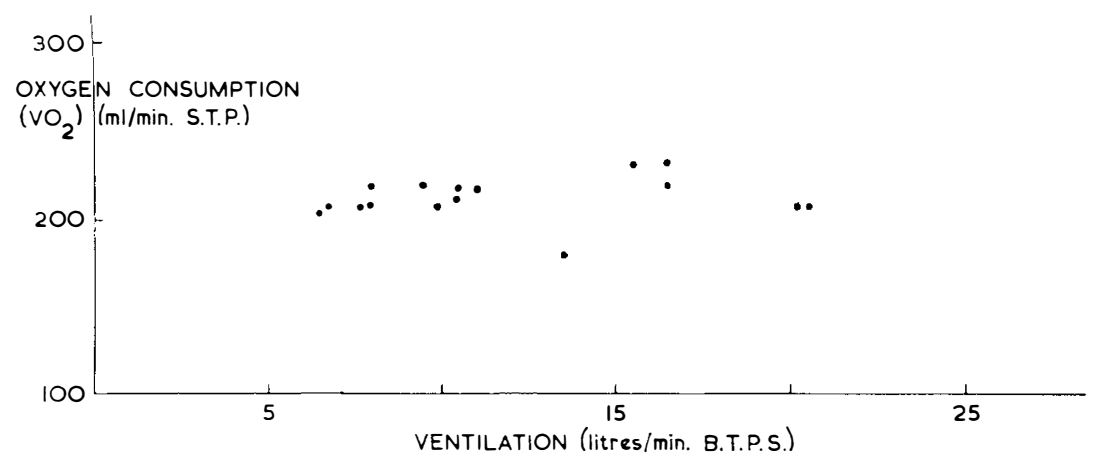

Fig. 5

C5 lesion F.J.H. Age 24 Injury 12.7.58

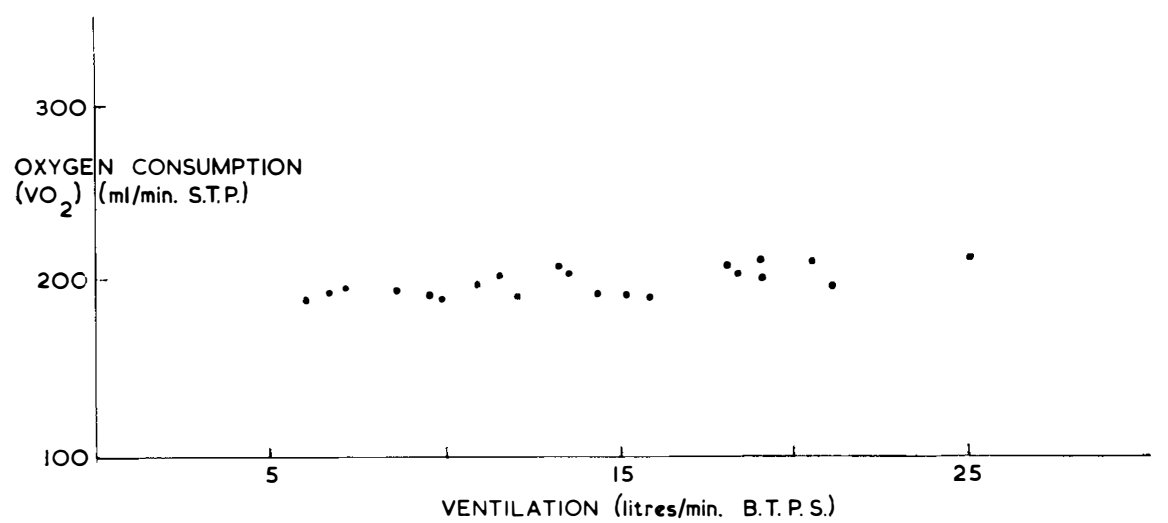

FIG. 6

C5 lesion D.P. Age 26 Injury 2.11.62

o 
The other resting figures are given in Table II; they were all between I 38 and $230 \mathrm{ml}$. per minute which is below the values given by Wade and Bishop (I962) of $234 \mathrm{ml}$. and Comroe et al. (I962) of $240 \mathrm{ml}$.

\section{TABLE II}

The Vital Capacity, Predicted Normal Vital Capacity, Oxygen Consumption per litre of excess ventilation and Resting Oxygen Consumption in I I tetraplegic patients.

\begin{tabular}{|c|c|c|c|c|c|c|c|}
\hline Name & Level & $\begin{array}{l}\text { Vital } C \\
\text { Vital } \\
\text { Capacity } \\
\quad(1 .)\end{array}$ & $\begin{array}{l}\text { apacity } \\
\text { Predic. } \\
\text { Normal } \\
\quad(1 .)\end{array}$ & $\begin{array}{l}\text { Max. Level } \\
\text { Ventilation } \\
\text { per minute } \\
\text { (l.) }\end{array}$ & $\begin{array}{l}\text { Min. Level } \\
\text { Ventilation } \\
\text { per minute } \\
\text { (1.) }\end{array}$ & $\begin{array}{c}\text { Oxygen } \\
\text { Consump. } \\
\text { ml./litre } \\
\text { excess } \\
\text { ventilation }\end{array}$ & $\begin{array}{l}\text { Resting } \\
\text { Oxygen } \\
\text { Consump. } \\
\text { (ml./min.) }\end{array}$ \\
\hline R. M. & $\mathrm{C}_{5}$ & $3 \cdot 2$ & $(4 \cdot 6)$ & $24 \cdot 75$ & 6 & 2 & 195 \\
\hline D. P. & $\mathrm{C}_{5}$ & $2 \cdot 2$ & $(4 \cdot 2)$ & 25 & 6 & $I \cdot I$ & 185 \\
\hline F. J. H. & $\mathrm{C}_{5}$ & $3 \cdot 76$ & $(4 \cdot 75)$ & $20 \cdot 5$ & $6 \cdot 5$ & 0.85 & 205 \\
\hline R. B. H. & $\mathrm{C}_{5}$ & $I \cdot 9$ & $(4 \cdot 6)$ & I7 & $5 \cdot 2$ & $2 \cdot 7$ & 180 \\
\hline E. H. H. & $\mathrm{C} 6$ & $3 \cdot 0$ & $(4 \cdot 0)$ & $29 \cdot 2$ & $5 \cdot 5$ & $\mathrm{I} \cdot 8$ & 205 \\
\hline J. F. H. & C6 & 3.63 & $(4 \cdot 15)$ & 19 & $5 \cdot 2$ & $\mathrm{I} \cdot 6$ & 140 \\
\hline D. T. & C6 & $I \cdot 5$ & $(2 \cdot 9)$ & 25 & 4.5 & $\mathrm{I} \cdot \mathrm{O}$ & 160 \\
\hline F. H. & $\mathrm{C}_{7}$ & 2 & $(4 \cdot 3)$ & $26 \cdot 75$ & $5 \cdot 2$ & $\mathrm{I} \cdot 3$ & I90 \\
\hline P. A. W. & $\mathrm{C}_{7}$ & I $\cdot 98$ & $(2 \cdot 9)$ & $2 \mathrm{I}$ & $4 \cdot 3$ & $\mathrm{I} \cdot 8$ & 138 \\
\hline M. O. & C8 & $4 \cdot 3$ & $(6 \cdot I)$ & 32 & $5 \cdot 5$ & $2 \cdot 6$ & 230 \\
\hline J. F. HG. & $\mathrm{T}_{3}$ & $3 \cdot 3$ & $(4 \cdot 3)$ & 25 & 6 & $\mathrm{r} \cdot 5$ & I 90 \\
\hline
\end{tabular}

There was a little scatter of the data and this may be due to the daily fluctuations in the metabolic state of the patient. It can be seen that within the limited range of ventilation which these patients could achieve there was little increase in the total oxygen consumption. This is in accordance with the findings of Campbell et al. (I957) in a normal subject but different from their findings in an emphysematous subject at similar levels of ventilation (fig. 7).

In all I I subjects a straight line was drawn through the data and from it the oxygen consumption per litre of increased ventilation was obtained.

The figures ranged from $0.85 \mathrm{ml}$. to $2.7 \mathrm{ml}$. per litre of excess ventilation with an average of $\mathrm{I} \cdot 6 \mathrm{ml}$. The vital capacity was also recorded and corrected to B.T.P.S. together with the predicted normal value derived from the height, age and sex of the subject as described by Baldwin, Cournand and Richards (I948). The maximum levels of ventilation achieved by the subjects were also recorded. This is not the same as the maximum breathing capacity as conventionally recorded, because in the determinations carried out in these experiments, the ventilation was recorded over 7-Io minutes while the subject was breathing through a length of rubber tubing. In the conventionally recorded determination, the procedure is restricted to 15 seconds.

\section{DisCUSSION}

It was found to be surprisingly easy to draw satisfactory slopes from the spirometer tracings in tetraplegic patients. This may have been due to the paralysis 

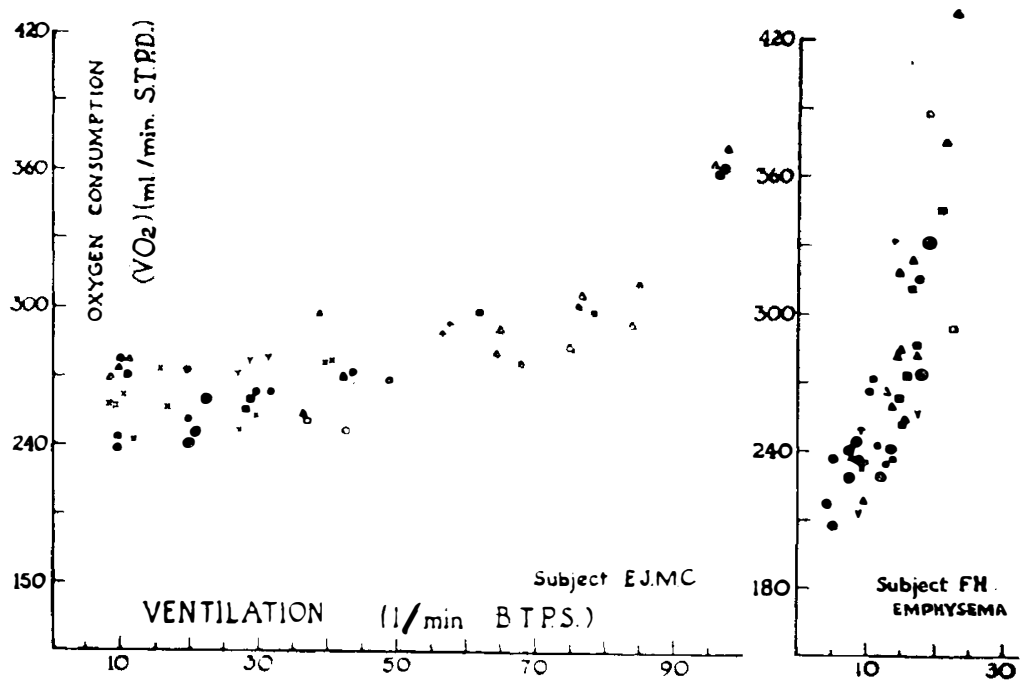

FIG. 7

Campbell, Westlake and Cherniak's (1957) findings on a normal subject and a patient suffering from emphysema. Note the much higher levels of ventilation achieved by the normal subject than the emphysematous subject and the three tetraplegic patients. See Figures 4, 5 and 6.

of a greater part of the patient's body which reduced sensory impulses from the body to a minimum and eliminated extraneous muscular activity apart from the spasms. The use of a spirometer circuit with a low resistance due to the motor blower may have been a contributory factor.

All the subjects behaved in the same way in that the oxygen consumption of the respiratory muscles remained constant up to the maximum levels of ventilation which these patients could achieve. It was an average of $\mathrm{I} \cdot 6 \mathrm{ml}$. of oxygen per litre of excess ventilation with a range of $0.85 \mathrm{ml}$. to $2.7 \mathrm{ml}$. in the eleven patients.

This is higher than the findings of Cournand and Richards (I954) of I ml. and that of Campbell et al. (1957) of $0.25 \mathrm{ml}$. in normal subjects, but considerably lower than their findings of $23 \mathrm{ml}$. and $7 \mathrm{ml}$. respectively in patients with cardiopulmonary disease at the same levels of ventilation.

It would appear that the oxygen consumption per litre of excess ventilation is a little higher than in normal subjects, and this may be because the patients are unable to use all their respiratory muscles, the intercostals and abdominals being paralysed.

The resting oxygen consumption in all I I patients was between I 38 and 230 $\mathrm{ml}$. of oxygen per minute, and this finding may be explained by the fact that the greater part of the subject's body is paralysed, thus reducing the total oxygen required by the body.

Cournand and Richards (1954), and Campbell et al. (1957) studied the oxygen consumption of the respiratory muscles up to levels of ventilation of roo litres per minute in normal subjects. They found that at the high levels of ventilation the oxygen consumption of the respiratory muscles rose disproportionately so that the 
relationship between the oxygen consumption and ventilation was not linear but a parabolic curve. In patients with cardiopulmonary disease this occurred at lower levels of ventilation (fig. 7). It was not
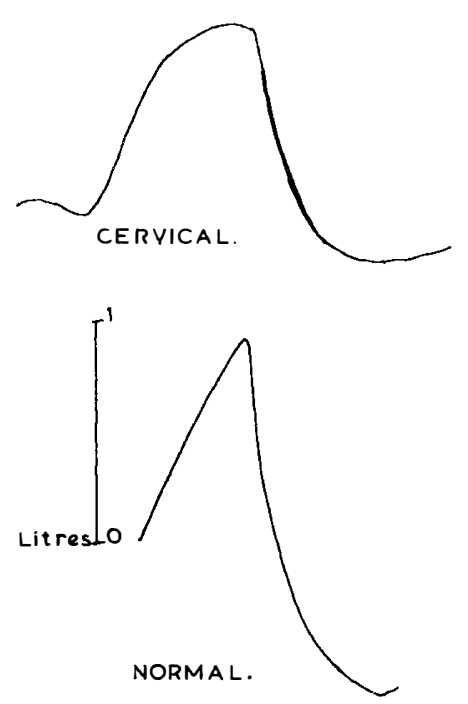

FIG. 8

Vital capacity in a cervical patient as compared with a normal subject; inspiration upwards. possible to study this relationship in tetraplegic patients as they were unable to achieve these high levels of ventilation. The gross reduction in the maximum levels of ventilation achieved by these subjects is quite disproportionate to the moderate reduction in the vital capacity. It may be explained by the functional disability produced by the paralysis of the main expiratory muscles, the abdominals. This paralysis results in an elimination of the expiratory reserve volume and a corresponding increase in the reserve volume of the lungs. Figure 8 shows the vital capacity of such a subject. Otis (I954) and Campbell (I958) have pointed out that with levels of ventilation up to two to three times the resting level expiration is entirely passive, being achieved by the passive elastic recoil of the chest tissues but that at higher levels of ventilation energy must be expended by the body in actively expelling the air from the lungs by the active contraction of the expiratory muscles. In tetraplegic patients the active expiration is profoundly impaired since their main expiratory muscles are paralysed, although Grossiord, Jaeger-Denavit

and Anamaria Miranda (1963) have produced some evidence suggesting that the shoulder girdle muscles may aid in expiration in tetraplegic subjects.

\section{CONCLUSION AND SUMMARY}

The oxygen consumption of the respiratory muscles of I I complete tetraplegic patients was measured using the method of Campbell et al. (1957), the principle of which is to measure the oxygen consumption of a subject at rest and at several levels of ventilation.

The oxygen consumption was measured by recording the disappearance of oxygen from a closed-circuit spirometer incorporating a motor blower and carbon dioxide absorber. Ventilation was increased by making the subject breathe through varying amounts of dead space provided by thick-walled rubber tubing.

It was found that the tetraplegics could not increase their ventilation above 32 litres per minute due to the paralysis of their expiratory muscles. At these levels the average oxygen consumption in all I I patients was I. $6 \mathrm{ml}$. per litre of excess ventilation with a range of $0.85 \mathrm{ml} .-2.7 \mathrm{ml}$. in the individual patients. This was higher than the findings of Cournand and Richards (1954) and Campbell et al. (I957) on normal subjects but much lower than their findings in patients with cardio-pulmonary disease. 
In all the tetraplegic patients the resting oxygen consumption was not above $230 \mathrm{ml}$. per minute.

It was concluded that while the ventilatory capacity in tetraplegic patients was severely reduced the oxygen consumption of the respiratory muscles was not excessive.

Acknowledgments. I wish to thank Dr. L. Guttmann for his constant encouragement and advice throughout the preparation of this work and Dr. E. J. M. Campbell for his help.

This work has been carried out with the aid of Grants from the Polio Research Fund and the Medical Research Council.

\section{RESUMÉ}

La consommation d'oxygène des muscles respiratoires de II tétraplègiques, avec atteinte complète, a été mesurée d'après la méthode de Campbell et coll. (I957) dont le principe est de mesurer la consommation d'oxygène d'un sujet au repos et à diffèrents niveaux de ventilation.

La consommation d'oxygène at été mesurée avec un spiromètre en circuit fermé et un absorbeur de $\mathrm{CO}_{2}$. La ventilation a été accrue en faisant réspirer le sujet à travers diffèrents éspaces morts crées par un tube, à paroi épaisse, en caoutchouc.

Il a été trouvé que les tétraplègiques ne pouvent acroitre leur ventilation au-dessus de 32 litres par minute, ceci étant dû a la paralysie des muscles expiratoires. A ces niveaux, la consommation moyenne d' $\mathrm{O}_{2}$, chez chacun des I I malades, était de I. $6 \mathrm{ml}$. par litre de ventilation éxcèdentaire avec des variations de $0.85 \mathrm{~m}$. à $2.7 \mathrm{ml}$. dans les cas individuels.

Ces résultats sont supérieurs à ceux de Cournaud et Richards (1954) et Campbell et ses collaborateurs (1957), sur des sujets normaux, mais inférieurs aux résultats trouvés chez des malades avec atteinte cardio-pulmonaire.

Chez tous les sujets tétraplègiques la consommation d'oxygène au repos était moins de $230 \mathrm{ml}$. par minute.

En conclusion, bien que la capacité respiratoire des tétraplègiques est sevèrement réduite la consommation d'oxygène des muscles respiratoires n'est pas excessive.

\section{ZUSAMMENFASSUNG}

Der Sauerstoffumsatz in den Atmungsmuskeln wurde in I I Tetraplegikern mit der Methode von Campbell et al. (I957) gemessen. Das Prinzip der Methode beruht auf der Messung des $\mathrm{O}_{2}$-Verbrauchs in Ruhe und bei verschiedenen respiratorischen Lagen.

Der $\mathrm{O}_{2}$-Verbrauch wurde bestimmt bei Messung des Verschwinden von $\mathrm{O}_{2}$ aus einem geschlossenen Spirometersystem, das mit einem $\mathrm{CO}_{2}-\mathrm{Absorber}$ versehen ist. Die Atmung wurde durch Einschalten verschiedener Grade eines toten Raums mit Hilfe eines dickwandigen Gummirohres verstärkt.

Es zeigte sich, dass Tetraplegiker ihre Ventilation nicht über 32 Liter per Minute infolge der Lähmung ihrer Atemmuskeln vermehren Können. Bei dieser Menge war der durchschnittliche $\mathrm{O}_{2}$-Verbrauch I $6 \mathrm{ml}$. per Liter mit einer Variation von $0 \cdot 85-2 \cdot 7$ für die individuellen Patienten. Dieses Ergebnis ist höher als die diejenigen von Cournand und Richards (1954) und Campbell et al. (1957) bei normalen Personen aber viel niedriger verglichen mit ihren Ergebuissen bei Patienten mit cardio-vasculären Erkrankungen. Minute.

In allen Tetraplegikern betrug der $\mathrm{O}_{2}-$ Verbrauch in Ruhe weniger als $230 \mathrm{ml}$. per

Der Verfasser kommt zu dem Schluss, dass der $\mathrm{O}_{2}$-Verbrauch in den Atmungsmuskeln nicht übermässig gross ist, obwohl die vitale ventilatorische Kapazität beim Tetraplegiker schwer reduziert ist.

\section{REFERENCES}

Baldwin, E. D. F., Cournand, A., \& Richards, D. W. (I948). Medicine, $27,243$.

Cameron, G. S., Scott, J. W., Jousse, A. T., \& Botterell, E. H. (1955). Ann. Surg., I4I, $45 \mathrm{I}$. 
Campbell, E. J. M., Westlake, E. K., \& Cherniak, R. M. (I957). F. Appl. Physiol., ir, 303.

CAMPBell, E. J. M. (1958). The Respiratory Muscles and the Mechanics of Breathing. London: Lloyd-Luke.

Comroe, J. H., Forster, R. E., Dubois, A. B., Briscoe, W. A., \& Carlsen, E. (I962). The Lung, Clinical Physiology and Pulmonary Function Tests. Chicago: Year Book Medical Publishers.

Cournand, A., \& Richards, D. W. (1954). Trans. Ass. Amer. Phycns., 67, 162.

Davidson, H. D., \& Cayler, G. G. (I963). F. Lab. clin. Med., 61, 292.

Gilliatt, R. W., Guttmann, L., \& Whitteridge, D. (1947). F. Physiol., 107, 67.

Grossiord, A., Jaeger-Denavit, \& Anamaria Miranda, G. (I963). Sem. Hôp. Paris, 663.

Hemingway, A., Bors, E., \& Hobby, R. P. (1958). F. clin. Invest., 37, 773.

Liljestrand, G. (I9I8). Scand. Arch. Physiol., 35, I99.

McKerrow, C. B., \& Otis, A. B. (1956). F. appl. Physiol., 9, 375.

Otis, A. B. (I954). Physiol. Rev., 34, 449.

Talbot, H. S., Rocco, A. G., \& Conroy, M. E. (1957). Proceedings of the 6th Annual Clinical Paraplegia Conference, p.20. Washington: American Veterans Administration.

Tribe, C. R. (1963). Int. F. Paraplegia, I, I9.

WADE, O. L., \& Bishop, J. M. (I962). Cardiac Output and Regional Blood Flow. Oxford: Blackwell.

Wingo, C. G. (1957). Proceedings of the 6th Annual Clinical Paraplegia Conference, p. 23. Washington: American Veterans Administration.

\section{ANNOUNCEMENT OF MEETING}

The third Annual Meeting of the Society, combined with a Scientific Meeting, will be held at Stoke Mandeville Hospital, Aylesbury, on the 24th and 25th July I964. The main subjects for discussion will be 'Social Aspects of Paraplegia' and 'Disturbance of Circulation in Paraplegia in Acute and Late Stages'. Will any member wishing to read a paper at the Meeting please write to the Secretary of the Society, Dr. J. J. Walsh, Stoke Mandeville Hospital, Aylesbury, Bucks.

It is hoped to hold a second Scientific Meeting in Tokyo during the period of the International Stoke Mandeville Games, which will take place in November, 1964, following the Olympic Games. Further details will be announced later. 